\title{
MENDORONG USAHA KECIL PEMBUATAN ARANG BATOK DI KELURAHAN CAMPANG RAYA KOTA BANDAR LAMPUNG
}

\author{
Muh Tohirin ${ }^{1}$, Iwan Zulfikar², Novalia ${ }^{3}$, Raditee Husin $^{4}$ \\ Program Studi Tehnik Mesin dan Manajemen \\ Universitas Sang Bumi Ruwa Jurai
}

\begin{abstract}
Abstrak
Pengabdian masyarakat yang dilakukan ini berjudul "Mendorong Usaha Kecil Pembuatan Arang Batok Di Kelurahan Campang Raya Kota Bandar Lampung”. Upaya membuat dan memproduksi tempurung kelapa menjadi nilai tambah yang lebih baik ternyata salah satunya adalah mengubah tempurung menjadi arang batok. Kepastian usaha dapat dilaksanakan dengan syarat usaha mikro ini terdukung dengan selalu ada dan selalu diterimanya produk arang batok oleh pedagang pengumpul arang. Adanya kepastian penerimaan arang batok menjadi daya dorong usaha mikro ini dapat bertahan namun pada hasil observasi ada kelemahan dari pelaku usaha ini yakni kurang modal dan kurangnya tenaga kerja serta kurangnya motivasi usaha. Usaha kecil pembuatan arang batok di Kelurahan Campang Raya Kota Bandar Lampung ini masih terkendala dengan keadaan tempat penampungan hasil produksi, artinya hasil produksi tergantung dari penerima yang masih berada di Provinsi Lampung dalam hal ini penampung yang berada di Kecamatan Natar Lampung Selatan dengan harga per kg untuk arang batok adalah Rp.3.800,-. Sedangkan kegundahan dari pengusaha setelah bercerita bahwa penampung tempat lain juga ada dalam hal ini adalah di Kota Bogor Jawa Barat hanya saja jumlah pasokan pengiriman arang batok dalam jumlah besar lebih dari 10 Ton dengan harga Rp. 10.000,- berbeda harga jauh dengan penerima di Lampung sendiri yang hanya dihargai sebesar Rp. 3.800,-. Kegundahaan inilah yang menjadi penyemangat pendamping karena apabila usaha yang menjadi dampingannya mengalami kemajuan akan menjadi kebahagiaan tersendiri terutama untuk civitas akademika dimana pendamping mengabdikan dirinya sebagai tenaga pengajar. Idealnya usaha ini dapat berkembang sebenarnya selain keseriusan atau kesungguhan dari pengusaha binaan ini adalah adanya bantuan informasi akan bentuk olahan arang batok ini dengan segala manfaat dan turunannya, seperti arang briket dan juga asap cair.
\end{abstract}

Kata kunci, Pengabdian,Masyarakat, UKM, Arang Batok

\begin{abstract}
This community service is entitled "Encouraging Small Businesses of Making Shell Charcoal in Campang Raya Village, Bandar Lampung City". One of the efforts to make and produce coconut shells into better added value is turning the shells into shell charcoal. Business assurance can be carried out on the condition that this microbusiness is supported by always being available and always receiving shell charcoal products by charcoal collectors. The certainty that the receipt of shell charcoal is the driving force for this micro business to survive, but based on the observations there are weaknesses of this business actor, namely lack of capital and lack of labor and lack of business motivation. The small business of making shell charcoal in Campang Raya Village, Bandar Lampung City is still constrained by the condition of the production place, meaning that the production depends on the recipient who is still in Lampung Province, in this case the container in Natar District, South Lampung at a price per $\mathrm{kg}$ for shell charcoal is Rp. 3,800,-.Meanwhile, the entrepreneur's anxiety after telling him that there is also another container, in this case, in the city of Bogor, West Java, it's just that the supply of large shell charcoal shipments is more than 10 tons at a price of Rp. 10,000, - is very different from the price of recipients in Lampung who are only valued at Rp. 3,800, -. This anxiety is also what encourages the companion because if the business that is assisting him is progressing it will be a special joy, especially for the academic community where the assistant devotes himself as a teacher. Ideally, this business can actually develop in addition to the seriousness or seriousness of the assisted entrepreneurs, namely the assistance of information on this form of processed shell charcoal with all its benefits and derivatives, such as charcoal briquettes and liquid smoke
\end{abstract}

Keywords :Community Service, Community, UKM, Charcoal Shell

\section{PENDAHULUAN}

Arang tempurung kelapa adalah produk yang diperoleh dari pembakaran tidak sempurna terhadap tempurung kelapa. Arang aktif dari tempurung kelapa memiliki daya saing yang kuat 
karena mutunya tinggi dan tergolong sumber daya yang terbarukan. Sebagai bahan bakar, arang lebih menguntungkan dibanding kayu bakar. Arang memberikan kalor pembakaran yang lebih tinggi dan asap yang lebih sedikit (Lemlit Pattimura, 2005; Pari, 2002).

Usaha arang batok tidak terlepas dari kegiatan sektor pertanian dalam hal ini sektor perkebunan yang notabene tanaman kelapa banyak tumbuh di negeri kita ini. Disinyalir pengembangan agribisnis kelapa berperan penting untuk peningkatan produktivitas dan sekaligus peningkatan pendapatan petani. Saat ini kelapa sangat berperan dalam perekonomian sebagai penyedia lapangan tenaga kerja, bahan baku industri dalam negeri dan konsumsi langsung. Meskipun demikian, kebanyakan usaha tani kelapa tidak terkait langsung dengan industri pengolahan, industri hilir, serta industri jasa dan keuangan. Akibatnya agribisnis kelapa tidak berhasil mendistribusikan nilai tambah, secara optimal dan proporsional, sehingga tidak signifikan pengaruhnya terhadap penambahan pendapatan petani kelapa. Pengelolaan usaha tani kelapa masih bersifat. tradisional dan terbatasnya modal, maupun kualitas produk yang dihasilkan masih rendah. Sampai saat ini belum banyak berubah sehingga komoditas kelapa yang mempunyai multiguna relatif tidak ada nilai tambahnya. Pangsa pasar ekspor sangat terbuka untuk semua produk kelapa, khususnya produk ikutan seperti bungkil, arang tempurung, sabut kelapa dan desicated coconut (ILO - PCdP2 UNDP: 30). Begitupun dengan penjelasan Kementerian Pertanian (2009 : 11) yang menyatakan bahawa untuk memberikan nilai tambah lebih besar, maka usahatani tidak cukup hanya sampai pada tahap menghasilkan produk primer saja, melainkan harus dilakukan kegiatan pengolahan dan pemasaran.

Sebagai produk turunannya, arang dari tempurung kelapa dapat diolah lebih lanjut menjadi bentuk briket yang mempunyai penampilan dan kemasan yang lebih menarik serta memiliki nilai ekonomis yang tinggi untuk dijadikan energi alternatif sehar-hari (Lafas, dkk., 2011). Briket adalah salah satu teknologi pemadatan (compaction) dalam kategori pemekatan (densification). Dalam pemekatan, materi ditekan menjadi produk yang kompak (high bulk density), mengandung sedikit air, mempunyai ukuran, bentuk dan sifat yang sama (Sutiyono, 2007).

Sebagai bentuk usaha lanjutan, pemanfaatan briket arang tempurung kelapa menjadi energi alternatif terbarukan merupakan langkah yang tepat bagi masyarakat untuk mengurangi ketergantungan terhadap bahan bakar fosil seperti minyak tanah dan gas elpiji, maupun pemanfaatan bahan bakar kayu yang tingkat konsumsinya semakin hari semakin meningkat tajam sehingga membahayakan ekologi hutan (Rizki, 2012). Apalagi ditengah krisis energi dan tingginya harga minyak bumi di pasar global saat ini menjadikan briket arang tempurung kelapa menjadi bahan bakar alternatif yang dapat diperbaruhi (renewable), murah dan ramah lingkungan.

Konsep nilai tambah merupakan konsep laba yang paling relevan dengan konsep pertanggung jawaban sosial perubahan. Sebab konsep lain (seperti: konsep laba bersih bagi perusahaan, investor dan pemegang saham), hanya berorientasi pada keuntungan satu pihak saja, tidak memperhatikan kontribusi pihak-pihak lainnya yang turut berpartisipasi dalam menghasilkan laba. Sedangkan konsep nilai tambah lebih didasarkan kepada kepentingan umum, bahwa bukan hanya pemilik perusahaan dan investor saja yang mempunyai kepentingan atas laba tetapi juga karyawan, pemerintah dan pihak-pihak lain yang telah memberikan kontribusi bagi perolehan nilai tambah. Sebab bagaimanapun perusahaan merupakan sebuah lembaga sosial dimana keputusan-keputusan yang diambil mempengaruhi sejumlah kelompokkelompok yang berkepentingan (Hendriksen 1982 dalamRabbihi 2011: 3).

Namun demikian dalam pelaksanaan observasi yang dilakukan dalam bentuk pengabdian pada usaha kecil mikro milik salah satu warga di Kelurahan Campang Raya Kecamatan Sukabumi Kota Bandar Lampung, oleh karena masih bermodalkan dana yang masih kecil, maka sebagai upaya usaha pemula adalah melakukan pembakaran tempurung kelapa 
hanya sebatas pembuatan Arang Batok saja tidak sampai pada kualitas arang batok briket. Industri lokal arang tempurung kelapa di Indonesia belum banyak berkembang secara profesional. Umumnya dikelola dengan investasi skala kecil dan teknologi yang sederhana akibat keterbatasan modal dan informasi pasar. Sehingga hal ini mempengaruhi kualitas dan kendala utama dalam pengembangan pengolahan arang briket. Usaha mikro ini hanya sebatas pesanan dari rekanan yang telah menjadi pelanggan, namun dalam upaya proses pemenuhan kontrak pemilik usaha kecil ini masih diselimuti kebimbangan dan juga rasa kurang percaya diri, seperti pembakaran yang seharusnya empat kali dalam satu bulan, terkadang hanya dua kali dalam satu bulan.Selanjutnya berdasarkan observasi dan tanya jawab sekaligus untuk memberi bimbingan, maka pemilik usaha arang batok ini sering berpindah tempat pada waktu pembakaran oleh karena adanya pengaduan dari masyarakat sekitar bahwa asap yang dihasilkan pada saat pembakaran telah menjadi gangguan lingkungan. Selain itu juga oleh karena pengetahuan yang belum dimiliki atau sesuatu hal lainnya, pemilik belum berfikir tentang persyaratan untuk mendirikan usaha pembakaran Arang Batok ini, misal ijin lingkungan, arus kas penggunaan dana pembakaran dan juga biaya pembuatan alat bakar. Dalam observasi ini terasa terpanggil apabila usaha kecil ini didampingi untuk menambah pengetahuan administrasi dan sosial, karena kemauan dan semangat pemilik besar.

\section{METODE}

Pelaksanaan pengabdian ini dilakukan dengan beberapa kali melakukan dialog dan anjang sana terutama kepada pengusaha arang batok. Adapun metode yang dilakukan oleh tim adalah memberikan bimbingan dan pandangan tentang pengembangan usaha arang batok. Berdasarkan pengamatan lapangan atau observasi dan tanya jawab, pemilik usaha arang batok ini sering berpindah tempat pembakaran, karena adanya pengaduan dari masyarakat sekitar bahwa asap yang dihasilkan pada saat pembakaran telah mencemari lingkungan. Dikarenakan pengetahuan yang dimiliki pemilik usaha

Arang batok kelapa belum terfikir tentang persyaratan untuk mendirikan usaha pembakaran Arang Batok ini, 459ijin lingkungan, arus kas penggunaan dana pembakaran dan juga biaya pembuatan alat bakar.

Kegiatan ini dilaksanakan oleh tim pengabdian yang merupakan tenaga pengajar dari Program Studi Teknik Mesin Fakultas Teknik dan Program Studi Manajemen Fakultas Ekonomi Universitas Sang Bumi Ruwa Jurai, yaitu:

1. Muh Thohirin

2. Iwan Zulfikar

3. Novalia

4. Radite Husin

Peserta kegiatan ini pelaku usaha Arang Batok. Kegiatan ini diselenggarakan tanggal 2 Maret 2020 bertempat di kediaman pengusaha arang batok ini di Kelurahan Campang Raya Kecamatan Sukabumi Kota Bandar Lampung. Dialog dengan menyertakan pemilik, istri, anak dan beberapa orang pekerja sebanyak 3 orang.

\section{Tahapan Review}

Naskah pengabdian ini dikirimkan kepada email : 1ppmsaburai@gmail.com 


\section{1.1Gambar dan tabel}

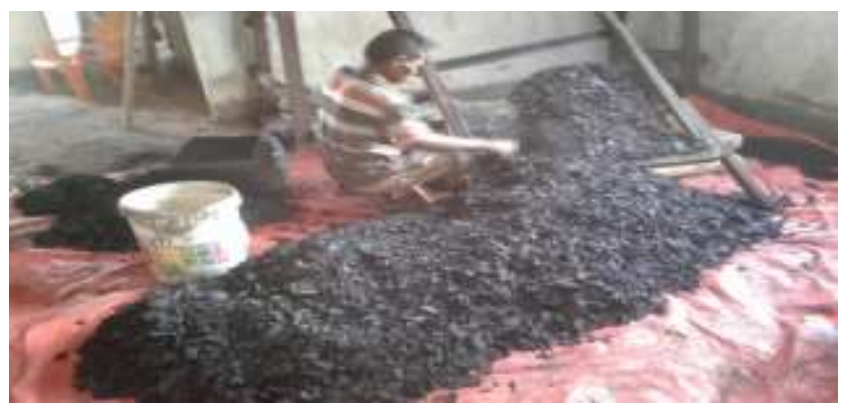

Gambar 2.1. Proses Pengayakan Arang Batok

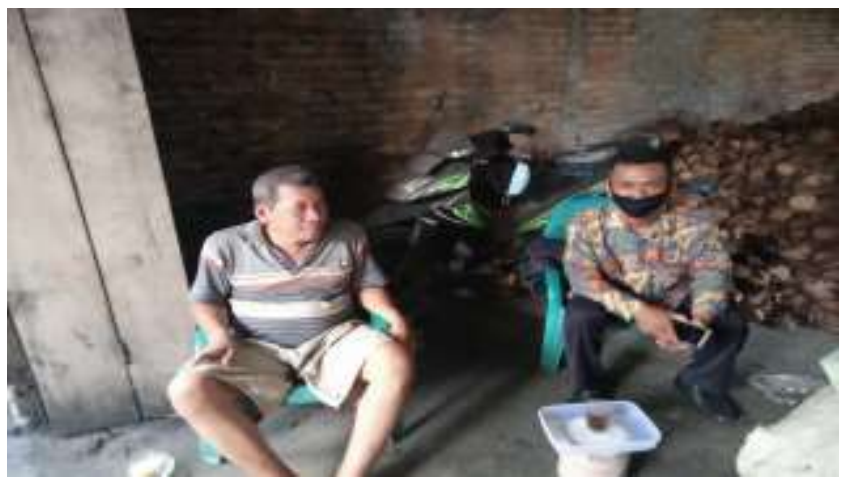

\section{Gambar 2.2. Dialog Rencana Pengembangan Usaha}

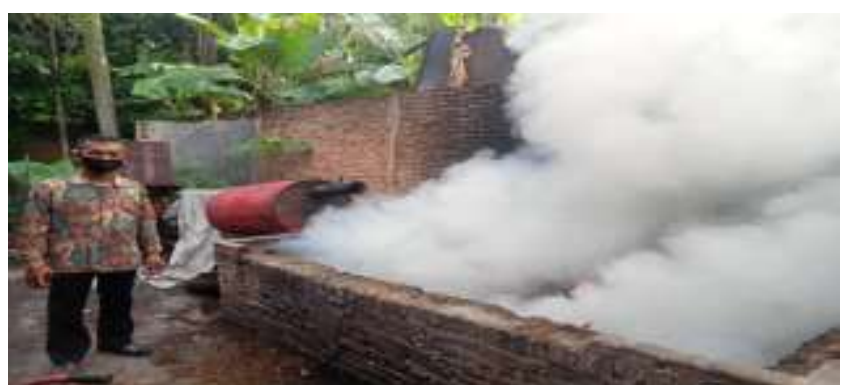

Gambar 2.3. Proses Pembuatan Arang

Berdasarkan hasil pembahasan permasalahan di atas maka dapat disimpulkan:

1. Pelayanan bantuan hukum secara cuma-cuma atau gratis dalam Undang-Undang Nomor 16 Tahun 2011 tertuang dalam Pasal 1 ayat 2 dan Pasal ayat 1 sampai dengan ayat 3 Undang-Undang Nomor 16 Tahun 2011 tentang Bantuan Hukum. Ruang lingkup Bantuan Hukun juga memuat penerima bantuan hukum dan hak dasar penerima bantuan hukum tercantum dalam Pasal 5 Undang-Undang Nomor 16 Tahun 2011 tentang Bantuan Hukum tertuang dalam ayat 1 dan ayat 2 .

2. Persyaratan dan mekanisme pelaksanaannya pelayanan bantuan hukum secara cuma-cuma atau gratis dalam Undang-Undang Nomor 16 Tahun 2011 di atur dalam Bab VI Syarat dan Tata Cara Pemberian Bantuan Hukum yang di jelaskan dalam Pasal 14 ayat 1 dan ayat 2, Pasal 15 ayat 1 sampai dengan ayat 5. 
Seminar Nasional Penelitian dan Pengabdian kepada Masyarakat

Universitas Sang Bumi Ruwa Jurai Tahun 2020

\section{. HASIL DAN PEMBAHASAN}

Sungguh sangat menggembirakan bila sesuatu yang menjadi harapan seseorang dapat tercapai. Begitu juga dengan upaya pembinaan terhadap suatu kegiatan yang melibatkan disiplin ilmu, akan menjadi kebahagiaan tersendiri bila objek yang menjadi perhatiannya dapat berhasil dan bahkan memberikan kesejahteraan tersendiri bukan hanya kepada pemilik usaha namun juga masyarakat sekitar yang dilibatkan dalam ketenaga kerjaan.

Usaha arang batok dengan proses pembakaran seadanya sebagaimana gambar 2.3. adalah masih merupakan upaya pembakaran arang batok yang dilakukan oleh pengusaha kecil di Kelurahan Campang Raya Kecamatan Sukabumi Kota Bandar Lampung.

Setelah melakukan pembakaran yang melibatkan hanya satu tenaga kerja, kekuatan dan semangat membuat arang batok menjadi terhambat, dan bahkan sering tidak tepenuhinya target dalam satu bulan yang seharusnya empat kali pembakaran, terkadang hanya dua kali pembakaran Usaha yang dilakukan selama ini dalam satu kali proses pembakaran dengan anggapan peralatan dianggap telah tersedia sebagai modal tetap, maka kebutuhan dalam satu kali pembakaran adalah sebagai berikut :

1. Batok Kelapa (10 ton) untuk modal pembuatan arang Rp. 6.000.000,-

2. Harga batok per/Kg Rp. 600,-

3. Solar 10 Liter x Rp. 6.000,- = Rp. 60.000,-

4. Bensin 1 leter Rp. 9.000,- (untuk pemancing membuat bara api yang untuk selanjutnya dikembangkan stabilitas api dengan menggunakan solar

5. Upah pembakaran untuk dua orang pekerja selama 14 Jam sampai dengan pengayakan Rp. 200.000,-

Itulah gambaran dari pelaksanaan pembakaran arang batok di Kelurahan Campang Raya Kecamatan Sukabumi Kota Bandar Lampung dengan gambaran apabila dikelola dengan sungguh-sungguh dan juga pengetahuan serta semangat yang tertanam dengan jiwa wirausaha, dipastikan usaha ini akan maju dan berkembang serta berkelanjutan sebagaimana usaha seperti ini dilakukan didaerah lain.

Apabila memperhatikan dari lokasi, kemauan dari pengusaha ini maka tidak menutup kemungkinan dengan mentalitas yang selalu dibarengi akan menjadi usaha yang lebih besar, sebagaimana usaha pembuatan arang batok dan briket bahkan asap cair di daerah Jambi yang dilakuak oleh Ade Yulia*, Fenny Permata Sari, Meri Arisandi, dimana dalam peneltiannya dengan judul "Analisis Kelayakan Pendirian Usaha Pengolahan Tempurung Kelapa di Kecamatan Pengabuan, Kabupaten Tanjung Jabung Barat, Provinsi Jambi“" sumber : Industria: Jurnal Teknologi dan Manajemen Agroindustri http://www.industria.ub.ac.id ISSN 2252-7877 (Print) ISSN 2548-3582 (Online) https://doi.org/ 10.21776/ub.industria.2019.008.02.7.

Menurut hasil penelitiannya bahwa Kabupaten Tanjung Jabung Barat memiliki produksi kelapa terbanyak di Provinsi Jambi dengan produksi pertahunnya adalah 51.066 ton. Produksi kelapa terbesar di Kabupaten Tanjung Jabung Barat terdapat di Kecamatan Pengabuan dengan produksi pertahunnya 12.523 ton (Badan Pusat Statistik Kabupaten Tanjung Jabung Barat, 2017). Pengolahan kelapa di Kecamatan Pengabuan hanya terfokus pada daging buah yang digunakan untuk pembuatan kopra. Kopra yang dihasilkan biasanya dijual kepada para pengumpul. Pembuatan kopra biasanya menghasilkan beberapa hasil samping (by-product) antara lain; sabut, tempurung dan air kelapa yang belum dimanfaatkan secara optimal. Salah satu hasil samping dari pembuatan kopra yang sangat potensial untuk dijadikan sumber energi terbarukan (renewable energy) adalah tempurung kelapa. Selama ini, di Kecamatan Pengabuan, 
tempurung kelapa di konversikan menjadi arang. Konversi limbah kelapa yang diterapkan masih sangat sederhana, biasanya pada pembuatan arang, tempurung kelapa dibakar di halaman terbuka dan asap hasil pembakaran dibiarkan begitu saja.

Proses konversi seperti ini sangat tidak efektif dan menghasilkan rendemen arang yang sangat rendah serta menimbulkan permasalahan yang besar bagi lingkungan yang disebabkan oleh polusi pembakaran tempurung kelapa. Tempurung kelapa dapat dijadikan asap cair dan briket. Asap cair merupakan gabungan larutan hasil penguraian asap didalam air dengan cara mengembunkan asap cair sisa dari pembakaran. Selama proses pembakaran, komponen utama bahan bakar yaitu selulosa, lignin, dan hemiselulosa akan terpirolisasi dan memproduksi tiga kelompok senyawa yaitu senyawa volatile yang dapat mengembun, gas yang tidak dapat mengembun serta zat arang. Kandungan kimia asap cair antara lain fenol, aldehid, keton, asam organik, alkohol dan ester. Bahan kimia tersebut dapat berfungsi sebagai antioksidan dan antimikroba yang akan berpengaruh terhadap warna dan cita rasa pada produk pangan (Putri \& Diana, 2015). Proses pembakaran tempurung kelapa akan menghasilkan asap cair. Hasil lanjutan dari olahan tempurung kelapa yang telah dibakar adalah biobriket dari tempurung kelapa. Biobriket tempurung kelapa dapat digunakan sebagai sumber bahan bakar. Biobriket tempurung kelapa digunakan karena lebih bersih, praktis dan menarik serta memiliki panas tinggi dan berkesinambungan serta tidak merusak lingkungan (Budijanto et al., 2008). Berat tempurung kelapa mencapai $12 \%$ dari total komposisi buah kelapa (Haryanto \& Suheryanto, 2004). Apabila tiap tahun Kecamatan Pengabuan mengoptimalkan 12.523 ton kelapa untuk membuat kopra, maka tiap tahun tempurung kelapa yang dihasilkan adalah 1.502,76 ton.

Penghasilan petani kelapa dapat ditingkatkan dengan mengubah pola usaha tani dari tradisional menjadi lebih produktif, berdaya guna, ekonomis, praktis dan mengarah pada pasar. Usaha pengolahan tempurung kelapa menjadi asap cair dan briket dari limbah padat produksi kopra di Kecamatan Pengabuan masih baru dan belum diketahui oleh petani kelapa, masyarakat ataupun pemerintah di kecamatan ini. Diperlukan studi kelayakan sebagai bahan pertimbangan untuk mendirikan suatu usaha. Dalam studi kelayakan dilakukan peninjauan terhadap aspek teknis, aspek pasar dan aspek finansial untuk mengetahui kelayakan dari pendirian usaha pengolahan tempurung kelapa. Kendala dan ancaman yang mungkin akan terjadi diharapkan dapat diminimalkan dengan adanya penilaian dari berbagai aspek tersebut. Selain itu juga aspek-aspek tersebut diharapkan dapat meminimalkan kemungkinanan terjadinya penyimpangan hasil yang ingin dicapai, sebagai referensi dalam mengambil keputusan untuk menyusun alternatif-alternatif guna kemajuan usaha serta dapat memberikan keuntungan bagi pihak-pihak yang terkait. Penelitian ini bertujuan untuk menganalisis kelayakan rencana pendirian usaha pengolahan tempurung kelapa menjadi asap cair dan briket di Kecamatan Pengabuan Kabupaten Tanjung Jabung Barat, Provinsi Jambi untuk menganalisis kelayakan rencana pendirian usaha pengolahan tempurung kelapa menjadi asap cair dan briket di Kecamatan Pengabuan Kabupaten Tanjung Jabung Barat Provinsi Jambi dilihat dari aspek teknis, pasar dan finansial.

Usaha kecil pembuatan arang batok di Kelurahan Campang Raya Kota Bandar Lampung ini masih terkendala dengan keadaan tempat penampungan hasil produksi, artinya hasil produksi tergantung dari penerima yang masih berada di Provinsi Lampung dalam hal ini penampung yang berada di Kecamatan Natar Lampung Selatan dengan harga per kg untuk arang batok adalah Rp. 3.800,-. Sedangkan kegundahan dari pengusaha setelah bercerita bahwa penampung tempat lain juga ada dalam hal ini adalah di Kota Bogor Jawa Barat hanya saja jumlah pasokan pengiriman arang batok dalam jumlah besar lebih dari 10 Ton dengan harga Rp. 10.000,- berbeda harga jauh dengan penerima di Lampung sendiri yang hanya dihargai sebesar Rp. 3.800,-. 
Kegundahaan inilah yang juga menjadi penyemangat pendamping karena apabila usaha yang menjadi dampingannya mengalami kemajuan akan menjadi kebahagiaan tersendiri terutama untuk civitas akademika dimana pendamping mengabdikan dirinya sebagai tenaga pengajar.

Idealnya usaha ini dapat berkembang sebenarnya selain keseriusan atau kesungguhan dari pengusaha binaan ini adalah adanya bantuan informasi akan bentuk olahan arang batok ini dengan segala manfaat dan turunannya, seperti arang briket dan juga asap cair.

Selain arahan dan binaan yang berhubungan dengan pelaksanaan usaha pembuatan arang batok, tentu saja faktor lain perlu diarahkan setidaknya diingatkan, seperti adanya upayaupaya pihak lain yang tidak senang dengan keberadaan pembakaran batok untuk menjadi arang batok ini dengan alasan lingkungan. Sebab berdasarkan informasi, ternyata di daerah Sukamulya Kecamatan Palas pernah terjadi penutupan pembuatan arang batok oleh warga, dimana saat musyawarah Dusun 5 Kuningan, Desa Sukamulya, Kecamatan Palas bersama pemilik usaha pembuatan arang dari tempurung kelapa, Minggu (23/9/2018) malam. Dalam musyawarah itu dihadiri langsung para tokoh dan warga yang terdampak asap dari usaha tersebut dan diketahui Kepala Desa Sukamulya, Pujiadi. Kepala Dusun Kuningan Desa Sukamulya, Muhamad Permadi, mengatakan dari musyawarah tersebut menghasilkan dua poin utama untuk Pengusaha Pembuatan Arang Batok Kelapa itu. Pertama masyarakat Dusun Kuningan menolak memberikan izin lingkungan dan menutup usaha itu.

Berdasarkan informasi sebagaimana terjadi di Palas itulah yang juga diberikan masukan kepada pemilik usaha agar hal seperti tersebut tidak terjadi di Kelurahan Campang Raya. Kelanggengan usaha Pembuatan Arang Batok sebagai produk pemula dan awal dalam jenis yakni hanya Arang Batok, maka analisa atau gambaran tentang batok atau tempurung adalah tergambarkan pada diskripsi seperti hal ini, yakni dimana dalam produk tempurung dimana berat dan tebal tempurung sangat ditentukan oleh jenis tanaman kelapa. Kelapa Dalam mempunyai tempurung yang lebih berat dan tebal daripada kelapa Hibrida dan kelapa Genjah. Tempurung beratnya sekitar 15-19\% dari bobot buah kelapa dengan ketebalan 3-5 mm. Komposisi kimia tempurung terdiri atas; Selulosa 26,60\%, Pentosan 27,70\%, Lignin 29,40\%, Abu $0,60 \%$, Solvent ekstraktif 4,20\%, Uronat anhidrat 3,50\%, Nitrogen $0,11 \%$, dan air $8,00 \%$ (Ibnusantoso, 2001).

Tempurung kelapa yang dulu hanya digunakan sebagai bahan bakar, sekarang sudah merupakan bahan baku industri cukup penting. Produk yang dihasilkan dari pengolahan tempurung adalah arang, arang aktif, tepung tempurung dan barang kerajinan. Arang aktif dari tempurung kelapa memiliki daya saing yang kuat karena mutunya tinggi dan tergolong sumber daya yang terbarukan.

Selain digunakan dalam industri farmasi, pertambangan, dan penjernihan, arang aktif juga digunakan untuk penyaring atau penjernih ruangan untuk menyerap polusi dan bau tidak sedap dalam ruangan. Berdasarkan data ekspor tahun 2003, Indonesia ternyata lebih banyak mengekspor dalam bentuk arang tempurung (56\%), sedangkan negara lain dalam bentuk arang aktif (APCC, 2000; APCC, 2001; APCC, 2003). Peningkatan ekspor arang tempurung dan arang aktif dalam kurun waktu 10 tahun terakhir masing-masing $13,86 \%$ untuk arang tempurung dan 6,1\% untuk arang aktif. Jumlah ekspor saat ini untuk arang tempurung dan arang aktif masing-masing 29.493 ton dan 11.553 ton.

Setelah tergambarkan tentang manfaat pengolahan tempurung, maka analisa ekonimi dan kandungannya terutama Analisis finansial pengolahan tempurung menjadi arang tempurung dilakukan dengan asumsi sebagai berikut:

a. Analisis dihitung untuk memproses hasil 1 ha kelapa atau sekitar 6.000 butir tempurung kelapa pertahun.

b. Produksi yang dihasilkan adalah arang tempurung. Setiap $1 \mathrm{~kg}$ arang tempurung membutuhkan sekitar 24 butir tempurung kelapa. 
c. Umur usaha dihitung selama 5 tahun sesuai dengan umur ekonomis tempat pembakaran.

d. Penyusutan dihitung per tahun berdasarkan estimasi umur ekonomis aset yang digunakan dengan metode garis lurus

e. Modal investasi, harga faktor produksi dan harga jual produk berdasarkan estimasi harga jangka panjang.

Discount rate yang digunakan sebesar $18 \%$ sesuai dengan estimasi tingkat suku bunga bank jangka panjang Perhitungan analisis finansial agro industri arang tempurung rakyat menunjukkan bahwa dengan harga produk arang tempurung $\mathrm{Rp} 500$,-/kg memberikan B/C ratio 1,11; NPV sebesar Rp 69.249,-; dan IRR 23\% (Tabel 1).

Tabel 1. Analisis finansial pengolahan arang tempurung tahun 2014 (5 tahun)

\begin{tabular}{|c|c|c|}
\hline URAIAN & TABLE II. & AKTUAL \\
\hline TABLE III. LUAS $\quad$ LAHAN & TABLE IV. & 1 \\
\hline $\begin{array}{l}\text { KELAPA BAHAN BAKU } \\
\text { (HA) }\end{array}$ & & \\
\hline $\begin{array}{l}\text { TABLE V. HARGA ARANG } \\
\text { TEMPURUNG }(\mathrm{RP} / \mathrm{KG})\end{array}$ & TABLE VI. & 500 \\
\hline $\begin{array}{l}\text { TABLE VII. DISCOUNT } \\
\text { FAKTOR }\end{array}$ & TABLE VIII. & $18 \%$ \\
\hline TABLE IX. NPV (RP) & TABLE $\mathrm{X}$. & 69.249 \\
\hline TABLE XI. B/C RATIO & TABLE XII. & 1,11 \\
\hline TABLE XIII. IRR & TABLE XIV. & $23 \%$ \\
\hline TABLE XV. SENSITIVITAS:*) & & \\
\hline TABLE XVI. LUAS & & \\
\hline KELAPA MINIMAL (HA) & TABLE XVII & 0,8 \\
\hline $\begin{array}{lc}\text { TABLE XVIII. } & \text { HARGA } \\
\text { MINIMAL } & \text { ARANG } \\
\text { TEMPURUNG }(\mathrm{RP} / \mathrm{KG})\end{array}$ & TABLE XIX. & 410 \\
\hline
\end{tabular}

Sumber: Mahmud et al. (2014).

Keterangan : ${ }^{*}$ Setiap perubahan satu variabel, variabel lain tetap

Analisis sensitivitas agroindustri ini menunjukkan bahwa dengan asumsi variabel yang lain tetap, harga minimal arang tempurung $\mathrm{Rp} 352,5$ / kg agar usaha tetap layak. Analisis ini juga menunjukkan bahwa dengan asumsi variabel lain tetap maka luas areal tanaman kelapa minimal yang diperlukan sebagai pendukung bahan baku sebesar 0,8 ha yang setara dengan 80 tanaman kelapa agar usaha tetap layak Kendala yang ada dalam pengembangan industri arang tempurung rakyat adalah masih kecilnya pasar produk arang tempurung ini sehingga jaminan pemasarannya sukar didapat.

\section{KESIMPULAN}

Simpulan dari pengabdian ini upaya membuat dan memproduksi tempurung kelapa menjadi nilai tambah yang lebih baik ternyata salah satunya adalah mengubah tempurung menjadi arang batok. Kepastian usaha dapat dilaksanakan dengan syarat usaha mikro ini terdukung dengan selalu ada dan selalu diterimanya produk arang batok oleh pedagang pengumpul arang. 
Seminar Nasional Penelitian dan Pengabdian kepada Masyarakat Universitas Sang Bumi Ruwa Jurai Tahun 2020

Adanya kepastian penerimaan arang batok menjadi daya dorong usaha mikro ini dapat bertahan namun pada hasil observasi ada kelemahan dari pelaku usaha ini yakni kurang modal dan kurangnya tenaga kerja serta kurangnya motivasi usaha.

Diharapkan untuk penelitian lanjut, diupayakan tidak hanya memprodukis arang batok, tetapi lebih baik apabila diarahkan pada arang cair.

\section{UCAPAN TERIMA KASIH}

Pengabdian ini merupakan kegiatan dari program kerja LPPM Universitas Sang Bumi Ruwa Jurai dimana menjadi kewajiban bagi dosen untuk melakukan pengabdian sebagai wujud kepedulian terhadap lingkungan yang dilihat dan menjadi kewajiban untuk disertakan dalam suatu kepedulian, dimana selain aspek ilmiah, keilmuan yang diterapkan namun ternyata aspek religi dalam bentuk amaliah menjadi ikut serta secara tidak disadari.

\section{DAFTAR PUSTAKA}

Sudiatmoko, Danang. 1998. Pemanfaatan Limbah Tempurung dan Campurannya dengan Tandan dan Sabut Kelapa Sawit Menjadi Arang Briket. Skripsi. Jurusan Teknologi Pengolahan Hasil Pertanian. Universitas Gadjah Mada. Yogyakarta.

Haygreen, J.G. dan J.L. Bowyer. 1989. Hasil Hutan dan Ilmu Kayu, Suatu Pengantar. Terjemahan oleh Sutjipto A. Hadikusumo (1989). Gadjah Mada University Press. Yogyakarta.

Hartoyo dan Nurhayati. 1978. Rendemen dan Sifat Arang dari Beberapa Jenis Kayu Indonesia. Buku Laporan Lembaga penelitian Hasil Hutan. Departemen Kehutanan. Bogor

Kementerian Pertanian. 2010. Outlook Komoditas Pertanian Perkebunan. http://pusdatin.deptan.go.id/admin/info/outlook_komoditas_bun.pdf. $\quad$ Diakses 04 Januari 2013.

Lafas, Hanandito dan Willy. 2011. Pembuatan Briket Arang Tempurung Kelapa Dari Sisa Bahan Bakar Pengasapan Ikan Keluragan Bandarharjo Semarang. Skripsi. Jurusan Teknik Kimia Fakultas Teknik. Universitas Diponegoro.

Masturin, A. 2002. Sifat Fisik dan Kimia Briket Arang dari Campuran Arang Limbah Gergajian Kayu. Skripsi. Fakultas Kehutanan, Institut Pertanian Bogor

Andayani, R., Wijana, S., \& Mulyadi, A. F. (2014). Analisis kelayakan teknis dan finansial pendirian unit pengolahan limbah tempurung kelapa (asap cair dan karbon aktif). Industria: Jurnal Teknologi Dan Manajemen Agroindustri, 3(3), 119-126 Badan Pusat Statistik Kabupaten Tanjung Jabung Barat. (2017). Kecamatan Pengabuan Dalam Angka 2017. Teluk Nilau: Badan Pusat Statistik Kabupaten Tanjung Jabung Barat.

Badan Pusat Statistik Provinsi Jambi. (2018). Provinsi Jambi Dalam Angka 2018. Jambi: Badan Pusat Statistik Provinsi Jambi.

Budijanto, S., Hasbullah, R., Prabawati, S., Setyadjit, Sukarno, \& Zuraida, I. (2008). Identifikasi dan uji keamanan asap cair tempurung kelapa untuk produk pangan. Jurnal Penelitian Pascapanen Pertanian, 5(1), 32-40.

Haryanto, T., \& Suheryanto, D. (2004). Pemisahan sabut kelapa menjadi serat kelapa dengan alat pengolah (defibring machine) untuk usaha kecil. In Seminar Rekayasa Kimia dan Proses. Semarang: Jurusan Teknik Kimia Fakultas Teknik Universitas Diponegoro.

Kotler, P. (2002). Manajemen Pemasaran (Milenium). Jakarta: Prenhallindo. 
Lestari, L., Aripin, Yanti, Zainudin, Sukmawati, \& Marliani. (2010). Analisis kualitas briket arang tongkol jagung yang menggunakan bahan perekat sagu dan kanji. Jurnal Aplikasi Fisika, 6(2), 93-96.

Maryono, Sudding, \& Rahmawati. (2013). Pembuatan dan analisis mutu briket arang tempurung kelapa ditinjau dari kadar kanji. Chemica: Jurnal Ilmiah Kimia Dan Pendidikan Kimia, 14(1), 74-83.

Muammar, Edison, \& Fathoni, Z. (2014). Analisis komparasi pendapatan usaha tani karet rakyat menggunakan bahan pembeku deorub dan non deorub di Kecamatan Jambi Luar Kota Kabupaten Muaro Jambi. Jurnal Ilmiah Sosio-Ekonomika Bisnis,17(1),111122.https://doi.org/10.22437/jiseb.v17i1.2798 Nurmalina, R., Sarianti, T., \& Karyadi, A. (2010). Studi Kelayakan Bisnis. Bogor: Butt Design Printing.

Pujawan, I. N. (2003). Ekonomi Teknik (Ed Pertama). Surabaya: Guna Widya.

Putra, M. M. C. (2015). Perencanaan Bisnis Asap Cair Tempurung Kelapa Melalui Pendekatan Wirakoperasi di Kabupaten Bogor. Skripsi. Departemen Agribisnis. Fakultas Ekonomi dan Manajemen. Institut Pertanian Bogor. Bogor.

Putri, R. E., \& Diana. (2015). Karakterisasi asap cair dari tempurung kelapa sebagai pengganti pengasapan tradisional pada ikan bili

Pari G. 2002. Teknologi Alternatif Pemanfaatan Limbah Industri Pengolahan Kayu. Makalah M.K. Falsafah sains. Program Pasca sarna IPB. Bogor

Rangkuti, Freddy. 2010. Business Plan: Teknik Membuat Perencanaan Bisnis dan Analisis Kasus. PT. Gramedia Pustaka Utama. Jakarta

Rizki, Odang Faidur. 2012. Karya Ilmiah Peluang Bisnis Briket Arang Dari Tempurung Kelapa. http://research.amikom.ac.id/index.php/STI/article. Diakses tanggal 01 Desember 2012.

Sutiyono. 2010. Pembuatan Briket Arang Dari Tempurung Kelapa Dengan Bahan Pengikat Tetes Tebu dan Tapioka. Jurnal Kimia dan Teknologi 3(2): 217222

Widiyanthi, Farida. 2007. Analisis Kelayakan Investasi Penambahan Mesin Vacuum Frying Untuk Usaha Kecil Pengolahan Kacang (Studi Kasus di PD. Barokah Cikijing Majalengka Jawa Barat). Skripsi. Program Sarjana Manajemen Agribisnis. Fakultas Pertanian. Institut Pertanian Bogor. Widodo, Ignatius Gunawan, Sutriyatna, Eko Widagdo. 2010. Upaya Penerapan Teknologi Pengolahan Arang Tempurung Kelapa Untuk Meningkatkan Nilai Tambah Petani di Kecamatan Sei Raya Kabupaten Bengkayang. Jurnal IPREKAS-Ilmu Pengetahuan dan Rekayasa 3(2): 8-13 